\title{
A longitudinal cohort study of Finnish patients with primary Sjögren's syndrome: clinical, immunological, and epidemiological aspects
}

\author{
M Pertovaara, E Pukkala, P Laippala, A Miettinen, A Pasternack
}

\begin{abstract}
Objective-To evaluate outcome in a cohort of Finnish patients with primary Sjögren's syndrome (pSS).

Methods-Clinical and laboratory data from the time of diagnosis and follow up were collected from 110 patients with pSS (107 women, three men) diagnosed in 1977-1992 in central Finland. The standardised incidence ratio for cancers was determined as the ratio of the observed number of cases to the expected number based on regional population rates. Eighty one of the 93 patients still alive were interviewed, and clinical and laboratory examinations performed in 1994-1997.

Results-The mean (SD) erythrocyte sedimentation rate (33 (22) $v \quad 45$ (28) mm/1st h), serum IgG (18.8 (7.4) $v 22.5$ $(8.5) \mathrm{g} / 1)$, and serum IgM (1.6 (1.1) $v 2.0$ (1.2) $\mathrm{g} / \mathrm{l})$ at the control visit were significantly $(p<0.0001)$ lower than those at baseline. A similar change was observed in a subgroup of patients never treated with glucocorticosteroids or disease modifying antirheumatic drugs. Three non-Hodgkin's lymphomas were diagnosed (standardised incidence ratio 13; $95 \%$ confidence interval 2.7 to 38 ). In a logistic regression model, the patients with pSS with subsequent lymphoma were found to have higher baseline levels of serum $\beta_{2}$ microglobulin than the others (odds ratio $1.9 ; 95 \%$ confidence interval 1.1 to 3.4$)$.

Conclusion-The results suggest that mean concentrations of serum IgG and IgM in patients with pSS decline with time, possibly reflecting diminishing inflammatory activity. As in previous studies, the incidence of non-Hodgkin's lymphomas in this cohort of patients with pSS was significantly higher than in the reference population.

(Ann Rheum Dis 2001;60:467-472)
\end{abstract}

The clinical course of Sjögren's syndrome (SS) has usually been regarded as chronic, mild, and stable. This has been confirmed in a recent long term follow up study of patients with SS. ${ }^{1}$

An increased risk of malignant lymphomas, especially of non-Hodgkin's type (NHL), was already clearly shown in the 1960s to be associated with SS. ${ }^{2}$ Subsequently, an epidemiological study showed the relative risk of developing malignant lymphoma in association with SS to be about 44 times higher than in the normal population. ${ }^{3}$ More recently, it has been suggested that the increased risk of lymphoma is particularly associated with primary SS (pSS). ${ }^{4}$ The lymphoma risk has been associated especially with extraglandular manifestations of SS such as lymphadenopathy, splenomegaly, parotid swellings, pulmonary infiltrates, renal insufficiency, hypergammaglobulinaemic purpura, leucopenia, and raised levels of serum $\beta_{2}$ microglobulin $\left(\beta_{2} \mathrm{~m}\right){ }^{5}$ Results to the contrary have also been reported. $^{4}$

Recent observations in a follow up study of Finnish patients with sicca symptoms showed that, in a median follow up time of 11 years, none of the 87 patients had developed lymphoma, although $36 \%$ fulfilled the criteria for possible or definite SS by the time of the follow up. ${ }^{6}$ In this study, we evaluated the outcome of Finnish patients with clearly established pSS. We determined possible changes in clinical and immunological findings over time, causes of death, and the incidence of lymphoproliferative disorders, as well as factors possibly predictive of or associated with lymphoproliferation among a cohort of patients with pSS.

\section{Patients and methods}

SELECTION OF PATIENTS

The records of all 408 patients with sicca symptoms initially examined in the Department of Internal Medicine, Section of Rheumatology, at Tampere University Hospital, Finland, during the years 1977-1992 were reviewed. A total of 110 patients (107 women, three men) fulfilled three (56\%) or more $(44 \%)$ modified $^{6}$ Californian criteria for $\mathrm{pSS}^{7}$ and comprised the study cohort. These 110 patients also fulfilled at least four of the European criteria for $\mathrm{pSS}^{8}$ and 77 of them (70\%) had a focus score of $\geqslant 1$ on labial salivary gland biopsy. Seventeen of them had died by the time of the control examinations (years 19941997). Baseline clinical and laboratory data (from the year of SS diagnosis in each case) on all 110 patients were collected from patient records. The 93 patients still living were invited by letter to an interview and clinical and laboratory examinations at the hospital. Eighty one of them (87\%) attended (six patients after a second invitation). In the case of the 12 non-attending patients and those who had died, follow up data comprised the clinical and laboratory findings from the most recent visit to the rheumatological outpatient clinic. The mean (SD) age of the 110 patients was 62 (13) years at the most recent visit. The median 
Table 1 Cumulative frequency of clinical characteristics and associated diseases in 110 patients with primary Sjögren's syndrome at the control visit

\begin{tabular}{lc}
\hline Characteristic & Frequency (\%) \\
\hline Symptoms of dry mouth & $97(88)$ \\
Symptoms of dry eyes & $86(72)$ \\
Arthralgia & $82(75)$ \\
Drug allergies & $62(56)$ \\
Raynaud's symptom & $55(50)$ \\
Recurrent salivary gland swelling & $50(46)$ \\
Myalgia & $49(45)$ \\
Persistent dry cough & $48(44)$ \\
Sensation of dyspnoea & $30(27)$ \\
Peripheral neurological symptoms & $23(21)$ \\
Arthritis & $24(22)$ \\
Purpura & $22(20)$ \\
Hypothyroidism & $18(16)$ \\
Lymphadenopathy & $17(16)$ \\
Pulmonary fibrosis & $17(16)$ \\
Pleurisy & $16(15)$ \\
Coeliac disease & $14(13)$ \\
Central nervous system symptoms & $12(11)$ \\
Enlarged liver or spleen & $10(9)$ \\
Diabetes & $7(6)$ \\
Primary biliary cirrhosis & $4(4)$ \\
Selective IgA deficiency & $3(3)$ \\
Pericarditis & $3(3)$ \\
Alveolitis & $3(3)$ \\
Renal stones & $2(2)$ \\
Overt distal renal tubular acidosis & $2(2)$ \\
Renal vasculitis & $1(1)$ \\
Child with a congenital complete heart block & $1(1)$ \\
Myositis & 0 \\
\hline &
\end{tabular}

duration of sicca symptoms in the eyes was at that time 10 years (range $0-41$ ), and that of xerostomia 11 years (range $0-40$ ). The median duration from the time of diagnosis of SS to the most recent visit was nine years (range $0.1-18$ ).

METHODS

The clinical examination included a thorough interview of the patients about family history, previous diseases, previous and current drug treatments, drug allergies, duration of sicca symptoms, first manifestation of SS, existence of recurrent parotid or submandibular gland swellings, and present sicca symptoms in the eyes and mouth. Special attention was focused on possible non-exocrine organ symptoms of SS (dermatological, endocrine, gastrointestinal, lymphoproliferative, musculoskeletal, neurological, renal, respiratory, and vascular). Purpura was defined as a history of typical episodic palpable purpura lesions in the lower limbs or skin biopsy. The diagnosis of coeliac disease was based on small bowel biopsy performed when clinically indicated. The diagnosis of primary biliary cirrhosis relied on liver histological examination with clinical indications. Enlargement of the liver or spleen was confirmed by ultrasound. Lymphadenopathy was defined as lymph node enlargement so persistent as to indicate a nodal biopsy in the opinion of the caring clinician. Arthritis was defined as articular swelling observed by a clinician. Myositis was diagnosed only if histological findings consistent with inflammation had been found on muscle biopsy. Peripheral and central neurological symptoms were recorded from the history given by the patients as well as from data from case histories. The diagnosis of pulmonary fibrosis was based on findings on chest radiographs.

The standard laboratory tests included whole blood count, erythrocyte sedimentation rate (ESR), serum total protein, serum creatinine, serum alanine aminotransferase, and serum alkaline phosphatase. Rheumatoid factor was determined by the Waaler-Rose agglutination test (at baseline) and by laser nephelometry (at follow up). Antinuclear antibodies were determined by indirect immunofluorescence on multiblock cryostat sections comprising rat liver and mouse kidney, heart and stomach (at baseline), and with Hep-2 cells (at follow up). Antibodies to extractable nuclear antigens, including antiribonucleoprotein, anti-Sm, anti-SSA, anti-SSB, and anti-Scl70, were measured by enzyme immunoassay (follow up). Serum concentrations of immunoglobulins (IgA, IgG, and $\operatorname{IgM}$ ), as well as serum complement levels (C3 and C4), were measured by laser nephelometry. Serum $\beta_{2} \mathrm{~m}$ was determined by radioimmunoassay (Pharmacia micro-RIA kit; Pharmacia Diagnostics, Uppsala, Sweden; reference values $1.0-2.5 \mathrm{mg} / \mathrm{l}$ ).

The incidence of malignant diseases in the patients from the time of SS diagnosis up to the end of 1996 was assessed from the files of the Finnish Cancer Registry. The total number of person years at follow up was 1015. The observed incidence of malignant diseases was compared with that expected in the age and sex matched population from the same University Hospital district, the reference rates also being calculated from the files of the Finnish Cancer Registry. The dates and causes of death of the patients with pSS were assessed from the time of SS diagnosis up to the end of 1996 through Statistics Finland.

STATISTICAL ANALYSIS

Student's $t$ test for paired samples was applied to compare differences in means of continuous variables between baseline and follow up. The McNemar test was used to compare dichotomous variables between baseline and follow up. Comparisons between different patient groups were performed by Mann-Whitney $U$ test and Fisher's exact two tailed test for continuous and dichotomous variables respectively. Logistic regression analysis by the backward stepwise method was applied to analyse risk factors for lymphoma development. The relative risk of malignant disease is presented using the observed to expected ratio - that is, the standardised incidence ratio (SIR) - with 95\% confidence intervals (95\% CI). The standardised mortality ratio was calculated as the ratio of the observed mortality in the cohort to data from Statistics Finland on the expected mortality in the Finnish general population of the same age, sex, and time.

\section{Results}

CLINICAL CHARACTERISTICS OF THE PATIENTS

AND ASSOCIATED DISEASES

Table 1 presents the cumulative clinical characteristics and associated diseases in the 110 patients by the time of the latest visit. At the time of the latest visit, eight of the 110 patients $(7 \%)$ were using a disease modifying antirheumatic drug (DMARD): hydroxychloroquine in four, sulfasalazine in one, and azathioprine in one patient with articular 
Table 2 Comparison of various immunoserological findings in patients with primary Sjögren's syndrome at baseline and at the control visit

\begin{tabular}{lllll}
\hline Variable & At baseline & At the control visit & $p$ Value & $n$ \\
\hline Haemoglobin $(\mathrm{g} / \mathrm{l})$ & $128(13)$ & $126(13)$ & $\mathrm{NS}$ & 107 \\
Leucocytes $\left(\times 10^{9} / \mathrm{l}\right)$ & $5.3(1.7)$ & $5.1(1.9)$ & $\mathrm{NS}$ & 107 \\
Thrombocytes $\left(\times 10^{9} / \mathrm{l}\right)$ & $257(70)$ & $248(69)$ & $\mathrm{NS}$ & 105 \\
ESR $(\mathrm{mm} / \mathrm{lst} \mathrm{h})$ & $45(28)$ & $33(22)$ & $<0.0001$ & 106 \\
Protein $(\mathrm{g} / \mathrm{l})$ & $79(7)$ & $77(9)$ & 0.024 & 86 \\
IgA $(\mathrm{g} / \mathrm{l})$ & $3.2(1.6)$ & $3.2(2.0)$ & $\mathrm{NS}$ & 101 \\
$\mathrm{IgG}(\mathrm{g} / \mathrm{l})$ & $22.5(8.5)$ & $18.8(7.4)$ & $<0.0001$ & 102 \\
$\mathrm{IgM}(\mathrm{g} / \mathrm{l})$ & $2.0(1.2)$ & $1.6(1.1)$ & $<0.0001$ & 101 \\
$\beta_{2} \mathrm{~m}(\mathrm{mg} / \mathrm{l})$ & $3.1(1.5)$ & $3.2(1.5)$ & $\mathrm{NS}$ & 88 \\
$\mathrm{C} 3(\mathrm{~g} / \mathrm{l})$ & $1.04(0.22)$ & $1.10(0.24)$ & 0.010 & 96 \\
$\mathrm{C} 4(\mathrm{~g} / \mathrm{l})$ & $0.17(0.08)$ & $0.18(0.10)$ & $\mathrm{NS}$ & 95 \\
Patients positive for & & & & \\
$\quad$ Rheumatoid factor & $46 \%$ & $74 \%$ & 0.001 & 80 \\
ANA & $67 \%$ & $83 \%$ & 0.008 & 103 \\
\hline
\end{tabular}

Values are means (SD).

$\mathrm{ESR}=$ erythrocyte sedimentation rate; $\mathrm{ANA}=$ antinuclear antibodies; $\mathrm{NS}=$ not significant.

symptoms. One patient with a vasculitic leg ulcer was treated with cyclosporin, and another patient with systemic vasculitis with cyclophosphamide. Prednisolone was in current use by 20 patients, in dosages from 2.5 to $10 \mathrm{mg}$ a day except for a higher dose in one patient with systemic vasculitis. The indications for steroid use included hypergammaglobulinaemic purpura, recurrent salivary gland swellings, and articular and pulmonary manifestations of pSS.

COMPARISON OF THE GLANDULAR AND IMMUNOSEROLOGICAL FINDINGS AT BASELINE AND CONTROL EXAMINATIONS

There were no significant differences in the incidence of dry eyes $(77 \% v 72 \%)$ or mouth $(94 \% v 88 \%)$ in the patients, or of recurrent parotid or submandibular gland swellings (39\% v 46\%) between baseline and control examinations.

Compared with baseline levels, there were no statistically significant differences in the follow up levels of blood haemoglobin, leucocytes, thrombocytes, serum alanine aminotransferase, serum alkaline phosphatase, or serum creatinine. Mean blood ESR at follow up was significantly lower than at baseline (33 (22) v $45(28) \mathrm{mm} / 1 \mathrm{st} \mathrm{h}, \mathrm{p}<0.0001)$. The follow up concentrations of serum protein (77 (9) $v 79$ (7) $\mathrm{g} / \mathrm{l}, \mathrm{p}=0.024)$, serum IgG (18.8 (7.4) v 22.5 (8.5) $\mathrm{g} / 1, \mathrm{p}<0.0001)$, and serum IgM (1.6 (1.1) v $2.0(1.2) \mathrm{g} / \mathrm{l}, \mathrm{p}<0.0001)$ were also significantly lower than those at baseline (table 2). The changes in these variables could not be attributed to treatment alone. In a subgroup of patients who had never received either glucocorticosteroid treatment or DMARDs $(n=38)$, the mean follow up ESRs (37 (24) v 42 (24) $\mathrm{mm} / 1 \mathrm{st} \mathrm{h}, \mathrm{p}=0.126, \mathrm{n}=37)$, serum IgG (20.4 (7.6) ข 23.4 (8.9) $\mathrm{g} / \mathrm{l}, \mathrm{p}=0.003, \mathrm{n}=35)$, and serum IgM (1.6 (0.6) v 2.1 (1.0) g/l, p=0.014, $\mathrm{n}=35$ ) were significantly lower than those at baseline.

SIR FOR LYMPHOPROLIFERATIVE DISORDERS AND OTHER MALIGNANCIES

By the end of 1996, three NHLs had developed in the 110 patients with pSS compared with 0.23 expected. The SIR of NHL in the whole cohort (men and women included) was thus 13 ( $95 \%$ CI 2.7 to 38 ). One case of myeloma was noted by the end of 1996; the expected number was 0.12 , and SIR was thus 8.3 (95\% CI 0.2 to 48). No cases of Hodgkin's disease were observed. The observed number of malignancies was not on the whole increased in this patient cohort: eight cases were observed and 7.1 expected; SIR 1.1 (95\% CI 0.5 to 2.2 ).

Table 3 presents the clinical, laboratory, and histological features in the patients with NHL (nos 1-3). One further patient (no 4) clinically had a picture of a lymphoproliferative disorder (a palpable abdominal mass, enlarged lymph nodes, and weight loss, as well as the highest serum $\beta_{2} \mathrm{~m}$ levels in the whole patient cohort; 8.0-12.4 mg/l). She died before the diagnostic examinations had been completed, and no autopsy was performed. Because of missing histological data, this case was not regarded in the analysis as a lymphoma case.

COMPARISONS OF THE BASELINE FINDINGS IN PATIENTS WITH NHL WITH THE REMAINDER The patients with pSS who developed lymphoproliferative diseases did not differ from the others with respect to baseline haemoglobin, leucocyte, thrombocyte, serum alanine aminotransferase, serum alkaline phosphatase, or serum creatinine levels. The mean concentrations of serum $\operatorname{IgA}(4.3(0.5) v 3.2(1.7) \mathrm{g} / \mathrm{l}$, $\mathrm{p}=0.072, \mathrm{n}=109), \operatorname{IgM}(3.2(0.8)$ v 2.0 (1.2) $\mathrm{g} / \mathrm{l}, \mathrm{p}=0.042, \mathrm{n}=108)$, and $\beta_{2} \mathrm{~m}(5.4$ (3.3) $v 3.2$ (1.5) $\mathrm{mg} / \mathrm{l}, \mathrm{p}=0.096, \mathrm{n}=99$ ) were higher, and serum complement C3 concentrations (0.83 (0.15) v $1.05(0.22) \mathrm{g} / \mathrm{l}, \mathrm{p}=0.068, \mathrm{n}=105)$ lower in the patients with subsequent lymphoma. There were no significant differences between the patient groups with respect to the mean concentration of serum IgG (24.4 (11.6) v $22.3(8.2) \mathrm{g} / \mathrm{l}, \mathrm{p}=0.707, \mathrm{n}=110)$ or in the frequencies of the positivity of antinuclear antibodies or the Waaler-Rose test at baseline.

In logistic regression analysis including baseline serum $\operatorname{IgA}, \operatorname{IgG}, \operatorname{Ig} M$, and $\beta_{2} \mathrm{~m}$ concentrations, as well as the baseline age in the model, serum $\beta_{2} \mathrm{~m}$ proved to be a significant predictor of lymphoma development in patients with pSS (OR 1.9; 95\% CI 1.1 to 3.4; $\mathrm{p}=0.031$ ).

The incidence of baseline clinical glandular findings such as dry eyes or mouth did not differ significantly between patients with subsequent lymphoma and those without $(100 \% v$ $77 \%$ and $100 \%$ v $94 \%$ respectively), nor did the incidence of a history of salivary gland swellings at baseline (33\% v 39\%). There were no significant differences in the incidence of abnormal results in baseline Schirmer $100 \% v$ $84 \%$ ) or Rose-Bengal tests ( $50 \%$ v $86 \%$ ) nor in the histological grades in sublabial salivary gland biopsies in those with subsequent lymphoma and the rest $(100 \%$ v $71 \%$ with more than grade 3 histology on the ChisholmMason scale ${ }^{9}$ ).

SMR AND CAUSES OF DEATH

All deceased patients in this pSS cohort were women. The standardised mortality ratio for female patients here was slightly increased (1.2). The observed number of deaths was 17 and that expected in an age, sex, and time 
Table 3 Clinical and laboratory findings in patients with primary Sjögren's syndrome and subsequent malignant lymphoproliferation and in one patient with suspected malignant lymphoproliferation

\begin{tabular}{|c|c|c|c|c|c|c|}
\hline \multirow{2}{*}{$\begin{array}{l}\text { Patient no; sex; } \\
\text { age at SS } \\
\text { diagnosis (years) }\end{array}$} & \multirow[b]{2}{*}{ Diagnostic criteria } & \multirow{2}{*}{$\begin{array}{l}\text { Extraglandular manifestations and } \\
\text { clinical features }\end{array}$} & \multicolumn{2}{|l|}{ Laboratory findings } & \multirow{2}{*}{$\begin{array}{l}\text { Time between } \\
\text { diagnoses of } \\
\text { SS and } \\
\text { lymphoma }\end{array}$} & \multirow{2}{*}{$\begin{array}{l}\text { Type of lymphoma and cause of } \\
\text { death }\end{array}$} \\
\hline & & & At baseline & At follow up & & \\
\hline \multirow[t]{6}{*}{ 1. Female, 56} & $\begin{array}{l}\text { Schirmer } 2 / 5 \mathrm{~mm} \text {, } \\
\mathrm{RB}+/+\end{array}$ & Parotid swellings, arthralgias & $\mathrm{S}-\beta_{2} \mathrm{~m} 9.2$ & $5.4 \mathrm{mg} / 1$ & \multirow[t]{6}{*}{2 years } & \multirow{6}{*}{$\begin{array}{l}\text { Malignant lymphocytic } \\
\text { lymphoma, large, } \\
\text { non-cleaved, stage IVA } \\
\text { Cause of death: generalised } \\
\text { lymphoma }\end{array}$} \\
\hline & Xerostomia + & Raynaud's, purpura, lymphadenopathy & S-IgG 25.00 & $9.25 \mathrm{~g} / 1$ & & \\
\hline & LSG grade 4 & $\begin{array}{l}\text { Liver and spleen enlargement, } \\
\text { pulmonary fibrosis }\end{array}$ & S-IgA 4.40 & $1.98 \mathrm{~g} / 1$ & & \\
\hline & Latex +, Wa-Ro + & $\begin{array}{l}\text { Pleurisy and pericarditis (in terminal } \\
\text { phase) }\end{array}$ & S-IgM 3.30 & $0.14 \mathrm{~g} / 1$ & & \\
\hline & $\mathrm{ANA}+$ & Oculomotorius and peroneal paresis & $\begin{array}{l}\text { S- } \gamma \text { globulin } \\
22.5\end{array}$ & $10.5 \mathrm{~g} / 1$ & & \\
\hline & ( $4 / 4$ criteria) & Pulmonary pseudolymphoma & ESR 56 & $\begin{array}{l}38 \mathrm{~mm} / 1 \mathrm{st} \\
\mathrm{h}\end{array}$ & & \\
\hline \multirow[t]{7}{*}{ 2. Female, 55} & $\begin{array}{l}\text { Schirmer } 4 / 3 \mathrm{~mm} \text {, BUT } \\
3 / 2 \mathrm{sec} \text {, }\end{array}$ & Parotid and submandibular swellings & $\mathrm{S}-\beta_{2} \mathrm{~m} 4.1$ & $5.0 \mathrm{mg} / 1$ & \multirow[t]{4}{*}{10 years } & \multirow[t]{2}{*}{$\begin{array}{l}\text { Ileum, malignant lymphoma, } \\
\mathrm{T} \text { cell type }\end{array}$} \\
\hline & $\mathrm{RB}-/-$ & Arthralgias & S-IgG 35.73 & $37.85 \mathrm{~g} / 1$ & & \\
\hline & Xerostomia + & Liver enlargement & S-IgA 4.67 & $7.98 \mathrm{~g} / 1$ & & \multirow{5}{*}{$\begin{array}{l}\text { Cause of death: ileal } \\
\text { perforation caused by } \\
\text { lymphoma }\end{array}$} \\
\hline & LSG grade 3-4 & Coeliac disease & S-IgM 2.32 & $3.53 \mathrm{~g} / 1$ & & \\
\hline & Latex + , Wa-Ro + & \multirow[t]{3}{*}{ Hypothyroidism } & $\begin{array}{l}\text { S- } \gamma \text { globulin } \\
33.4 \mathrm{~g} / 1\end{array}$ & - & \multirow[t]{3}{*}{-} & \\
\hline & $\mathrm{RNP}+, \mathrm{SSA}+, \mathrm{SSB}+$ & & ESR 49 & $\begin{array}{l}90 \mathrm{~mm} / 1 \mathrm{st} \\
\mathrm{h}\end{array}$ & & \\
\hline & ( $3 / 4$ criteria) & & & & & \\
\hline \multirow[t]{5}{*}{ 3. Female, 71} & Schirmer 4/8, RB ND & Arthralgias and arthritis & $\mathrm{S}-\beta_{2} \mathrm{~m} 2.9 \mathrm{mg} / 1$ & - & \multirow[t]{5}{*}{4 years } & \multirow{5}{*}{$\begin{array}{l}\text { Malignant lymphoma, diffuse } \\
\text { centroblastic centrocytic } \\
\text { Cause of death: pneumonia } \\
\text { and staphylococcal } \\
\text { septicaemia }\end{array}$} \\
\hline & Xerostomia + & Lymphadenopathy & S-IgG 12.50 & $10.39 \mathrm{~g} / 1$ & & \\
\hline & LSG grade 3 & Pleurisy (associated with pneumonia) & S-IgA 3.73 & $3.06 \mathrm{~g} / 1$ & & \\
\hline & & \multirow[t]{2}{*}{$\begin{array}{l}\text { Dizziness, lesio vestibularis trunchi } \\
\text { cerebri }\end{array}$} & S-IgM 3.98 & $2.99 \mathrm{~g} / 1$ & & \\
\hline & $(3 / 4$ criteria) & & ESR 42 & $\begin{array}{l}23 \mathrm{~mm} / 1 \mathrm{st} \\
\mathrm{h}\end{array}$ & & \\
\hline \multirow[t]{6}{*}{ 4. Female, 64} & Schirmer ND, RB-/+ & Submandibular swellings & $\mathrm{S}-\beta_{2} \mathrm{~m} 8.0$ & \multirow[t]{6}{*}{$12.4 \mathrm{mg} / 1$} & \multirow[t]{6}{*}{0 years } & \multirow{6}{*}{$\begin{array}{l}\text { Nodal biopsy? (to be taken) } \\
\text { Cause of death: SS and CHF } \\
\text { (no autopsy) }\end{array}$} \\
\hline & Xerostomia + & Arthralgias, Raynaud's & S-IgG $23.97 \mathrm{~g} / 1$ & & & \\
\hline & LSG grade 4 & Trigeminal neuralgia & S-IgA $2.27 \mathrm{~g} / 1$ & & & \\
\hline & Latex 0, Wa-Ro 0 & Liver enlargement & S-IgM $0.55 \mathrm{~g} / 1$ & & & \\
\hline & & $\begin{array}{l}\text { Massive lymphadenopathy and } \\
\text { abdominal tumour }\end{array}$ & $\begin{array}{l}\text { S- } \gamma \text { globulin } \\
18.6 \mathrm{~g} / 1\end{array}$ & & & \\
\hline & ( $3 / 4$ criteria) & & $\begin{array}{l}\text { ESR } 58 \mathrm{~mm} / 1 \mathrm{st} \\
\mathrm{h}\end{array}$ & & & \\
\hline
\end{tabular}

RB = Rose-Bengal test; LSG = labial salivary gland biopsy; Wa-Ro = Waaler-Rose test; ANA = antinuclear antibodies; S- $\beta_{2} \mathrm{~m}=$ serum $\beta_{2}$ microglobulin; ESR = erythrocyte sedimentation rate; $\mathrm{SS}=\mathrm{S}$ jögren's syndrome; $\mathrm{CHF}=$ congestive heart failure; $\mathrm{ND}=$ not done; $\mathrm{RNP}=$ ribonucleoprotein; $\mathrm{RF}=$ rheumatoid factor.

matched general Finnish population was 14 . Table 4 presents the causes of death in the 17 patients with pSS. The expected number of deaths of male patients was 0.4 .

\section{Discussion}

The proportion of our patients attending the interview and clinical and laboratory examinations was high (87\%), and, as all remaining patients had also visited our outpatient clinic for regular check ups, we consider that clinical and laboratory data on these patients could also be obtained fairly reliably.

The clinical characteristics and occurrence of non-exocrine organ features in our patients

Table 4 Cause of death in 17 patients with primary Sjögren's syndrome

\begin{tabular}{lcc}
\hline Cause of death & No of patients & Autopsy performed \\
\hline Cardiovascular & 6 & 1 \\
$\quad$ Congestive heart failure & 5 & - \\
$\quad$ Myocardial infarction & 1 & - \\
Cerebrovascular & 3 & - \\
$\quad$ Cerebral infarction or haemorrhage & 3 & 2 \\
Malignancy & 4 & - \\
$\quad$ Malignant lymphoma & 2 & - \\
Sigmoid cancer & 1 & 1 \\
Rectal cancer & 1 & - \\
Infection & 3 & 1 \\
Pneumonia & 2 & 5 \\
Meningoencephalitis and osteomyelitis & 1 & 5 \\
Drug intoxication & 1 & \\
Total & 17 & \\
\hline
\end{tabular}

with pSS are in fair accord with previous findings. ${ }^{10-14}$ In the course of time, ESR and the concentrations of serum IgG and $\operatorname{IgM}$ were found to decrease in our patients with pSS. Previously, a fall in levels of serum $\gamma$ globulins, especially $\operatorname{IgM}$ and autoantibodies, has been found to accompany or precede the onset of lymphoid malignancies in patients with SS. ${ }^{5}{ }^{15}$ In our study, a decrease in serum IgG and IgM concentrations was observed in the whole patient group and not confined to the patients with lymphoma. A significant decrease in serum IgG and IgM and ESR has previously been found in patients with pSS during treatment with hydroxychloroquine compared with placebo. ${ }^{16}$ In our study, this change could not be attributed to treatment alone, as it also occurred in patients who had never been treated with either glucocorticosteroids or DMARDs.

An age related increase in serum $\operatorname{IgA}$ and IgG concentrations has been shown in several studies of healthy populations. ${ }^{17-20}$ In an earlier follow up study of patients with SS, ${ }^{1}$ including 21 with pSS, a decrease in mean serum IgG concentration was noted, as in the present study. In that study, however, no statistically significant differences in the concentrations of serum IgM or IgA or ESR were found during the follow up. ${ }^{1}$ Whether the decline over time 
observed here in serum IgG and IgM concentrations in patients with pSS reflects a risk of developing lymphoid malignancies, as previously suggested, ${ }^{515}$ or is caused merely by the diminishing inflammatory activity of pSS remains to be elucidated. The observed increase over time in mean C3 concentrations in patients with pSS would favour the latter. Furthermore, in one of our three patients with subsequent lymphoma, a decrease in serum immunoglobulins was not observed over time.

In this study, the proportion of patients with positive rheumatoid factor and antinuclear antibodies was significantly higher at follow up than at baseline. However, it is possible that, in addition to increasing age, the use of more sensitive methods of determination may have contributed to these results.

In accord with previous studies, ${ }^{1-5}{ }^{11-14}{ }^{21-24}$ an increased risk of NHL in patients with SS was observed here. It has been suggested that malignant lymphomas are more common in pSS than in secondary SS. ${ }^{4}$ In an epidemiological cohort study of 676 patients with pSS, 709 with secondary SS, and 9469 with rheumatoid arthritis identified from the Finnish national hospital discharge register, the SIR of NHL was found to be $8.7,4.5$, and 2.2 respectively. ${ }^{22}$ The present study dealt specifically with patients with pSS, and the risk of NHL was clearly higher than that in the general population of the same age, sex, and region. As in the study by Kassan and colleagues, ${ }^{3}$ the incidence of malignancies other than lymphoid was not increased.

A spectrum of lymphoproliferative disorders has been described in association with $\mathrm{SS}^{25-34}$ but most of the lymphomas complicating the course of SS are derived from B lymphocytes. ${ }^{25}$ Three of our patients developed NHL, one of them being an ileal $\mathrm{T}$ cell lymphoma, a form unusual in SS. ${ }^{26-30}$

There are few identified prognostic markers for the development of lymphoma in SS. Usually, patients with SS who develop lymphoid neoplasms have had severe sicca syndrome with many of its complications. ${ }^{35} 36$ These observations could not be confirmed by McCurley et $a l^{4}$ In a recent European multicentre study, lymphadenopathy, skin vasculitis, peripheral nerve involvement, low grade fever, anaemia, and lymphopenia were observed more often in SS patients with NHL than in those without. ${ }^{37}$ Like in that study, our patients who developed lymphoma had several non-exocrine organ features of SS, as shown in table 3. However, no statistically significant differences were observed in clinical characteristics at baseline, at least the glandular findings, compared with other patients.

In addition to non-exocrine manifestations of pSS, ${ }^{23}{ }^{35-37}$ mixed monoclonal cryoglobulinaemia $^{24} 38$ and monoclonal rheumatoid factor associated cross reactive idiotype ${ }^{38}$ have been identified as factors predictive of lymphoma development in patients with pSS. Molecular analysis of the labial salivary glands has suggested that identification of B cell monotypia is predictive of the development of lymphoma elsewhere. ${ }^{39}$ In our study, the number of patients with malignant lymphoproliferation was small; nevertheless, those with subsequent lymphoma had higher baseline $\operatorname{Ig} \mathrm{A}, \operatorname{Ig} M$, and $\beta_{2} \mathrm{~m}$ levels than those without.

Raised levels of serum $\beta_{2} \mathrm{~m}$ have previously resulted from renal $^{40}{ }^{41}$ and lymphoproliferative $^{40}$ complications of SS. We have previously found raised serum $\beta_{2} \mathrm{~m}$ and IgG levels to be predictive of the development of SS in patients with sicca symptoms. ${ }^{6}$ In the present study, high serum $\beta_{2} \mathrm{~m}$ was found to be an independent predictive factor for lymphoma development in patients with pSS.

Hitherto, only one population based cohort study on survivorship in $\mathrm{SS}^{42}$ has been published; patients with pSS were not found to have increased mortality. The standardised mortality ratio for female patients with pSS in our cohort was likewise only slightly increased compared with that of the general population.

In conclusion, in this follow up study of patients with pSS, declining levels of serum IgM and IgG were found not to be restricted to patients who developed lymphoid malignancy, as previously suggested, ${ }^{515}$ but were encountered in the whole patient cohort. This tendency was not explained by treatment. The increased risk of NHL in patients with pSS was confirmed in this study as elsewhere. ${ }^{2}{ }^{3}$ The patients with pSS with subsequent lymphoma development had higher baseline serum $\beta_{2} \mathrm{~m}$ levels than the others. Thus, the possibility of subsequent malignant lymphoproliferation should be considered, especially in patients with raised baseline serum $\beta_{2} \mathrm{~m}$ concentrations. This study was supported by a grant from the Medical Research
Fund of Tampere University Hospital. We wish to thank Anni Fund of Tampere University Hospital. We wish to thank Anni
Vilppula, MD, PhD, who initiated research on Sjögren's Vilppula, MD, PhD, who initiated research on Sjögren's
syndrome at the Section of Rheumatology in the Department of syndrome at the Section of Rheumatology in the Department
Internal Medicine in Tampere University Hospital in 1977.

1 Kruize AA, Hené RJ, van der Heide A, Bodeutsch C, Wilde PCM, van Bijsterveld OP, et al. Long-term follow-up of patients with Sjögren's syndrome. Arthritis Rheum patients with Sjogr

2 Bloch K, Buchanan W, Wohl M, Bunim J. Sjögren's syndrome: a clinical, pathological and serological study of sixty-two cases. Medicine (Baltimore) 1965;44:187-231.

3 Kassan SS, Thomas TL, Moutsopoulos HM, Hoover R, Kimberly RB, Budman DR, et al. Increased risk of lymphoma in Sjögren's syndrome. Ann Intern Med 1978;89:888-92.

4 McCurley T, Collins R, Ball E, Collins R. Nodal and extranodal lymphoproliferative disorders in Sjögren's syndrome: a clinical and immunopathologic study. Hum Pathol 1990;21:482-92.

5 Talal N, Bunim JJ. Development of malignant lymphoma in the course of Sjögren's syndrome. Am J Med 1964;36:52940.

6 Pertovaara M, Korpela M, Uusitalo H, Pukander J, Miettinen A, Helin H, et al. Clinical follow-up study of 87 patients with sicca symptoms (dryness of eyes or mouth, or poth). Ann Rheum Dis 1999;58:423-7.

7 Fox RI, Robinson CA, Curd JG, Kozin F, Howell FV. Fox RI, Robinson CA, Curd JG, Kozin F, Howell FV. Sjögren's syndrome. Proposed criter
Arthritis Rheum 1986;29:577-85.

8 Vitali C, Bombardieri S, Moutsopoulos HM, Balestrieri G, Bencivelli W, Bernstein RM et al. Preliminary criteria for the classification of Sjögren's syndrome: results of a prospective concerted action supported by the European Community. Arthritis Rheum 1993;36:340-7.

9 Chisholm DM, Mason DK. Labial salivary gland biopsy in Sjögren's syndrome. J Clin Pathol 1968;21:656-60.

10 Pavlidis A, Karsh J, Moutsopoulos H. The clinical picture of primary Sjögren's syndrome: a retrospective study. J Rheumatol 1982;9:685-90.

11 Kelly CA, Foster H, Pal B, Gardiner P, Malcolm AJ, Charles $\mathrm{P}$, et al. Primary Sjögren's syndrome in North East England: a longitudinal study. Br J Rheumatol 1991;30: 437-42.

12 Markusse HM, Oudkerk M, Vroom TM, Breedveld FC. Primary Sjögren's syndrome: clinical spectrum and mode of presentation based on an analysis of 50 patients selected from a department of rheumatology. Neth J Med 1992;40: from a depar. 
13 Pease CT, Charles PJ, Shattles W, Markwick J, Maini RN. Serological and immunogenetic markers of extraglandular
primary Sjögren's syndrome. Br J Rheumatol 1993;32: primary

14 Davidson BK, Kelly CA, Griffiths ID. Primary Sjögren's syndrome in the North East of England: a long-term follow-up study. Rheumatology 1999;38:245-53.

15 Whaley K, Webb J, McAvoy BA, Hughes GRV, Lee P, MacSween RNM, et al. Sjögren's syndrome 2. Clinical associations and immunological phenomena. QJM 1973;167: 513-48.

16 Kruize AA, Hené RJ, Kallenberg CGM, van Bijsterveld OP, van der Heide A, Kater L, Bijlsma JWJ. Hydroxychloroquine treatment for primary Sjögren's syndrome: a two year double blind crossover trial. Ann Rheum Dis 1993;52: $360-4$.

17 Riesen W, Keller H, Skvaril F, Morell A, Barandun S. Restriction of immunoglobulin heterogeneity, autoimmunity and serum protein levels in aged people. Clin Exp Immunol 1976;26:280-5.

18 Batory G; Jancso A, Puskas E, Redei A, Lengyel E. Antibody and immunoglobulin levels in aged humans. Arch Gerontol and immunoglobulin leve

19 Rajczy K, Vargha P, Beregi E. Relationship between immunoglobulin levels and specific antibody titers in the elderly. Z Gerontol 1986;19:158-61.

20 Paganelli R, Quinti I, Fagiolo U, Cossarizza A, Ortolani C, Guerra $\mathrm{E}$, et al. Changes in circulating $\mathrm{B}$ cells and immunoglobulin classes and subclasses in a healthy aged population. Clin Exp Immunol 1992;90:351-4.

21 Pavlidis NA, Drosos AA, Papadimitriou C, Talal N, Moutsopoulos H. Lymphoma in Sjögren's syndrome. Med Pediatr Oncol 1992;20:279-83.

22 Kauppi M, Pukkala E, Isomäki $\mathrm{H}$. Elevated incidence of hematologic malignancies in patients with Sjögren's syndrome compared with patients with rheumatoid arthritis (Finland). Cancer Causes Control 1997;8:201-4.

23 Anderson LG, Talal N: The spectrum of benign to malignant lymphoproliferation in Sjögren's syndrome. Clin malignant lymphoproliferation in

24 Zufferey P, Meyer OC, Grossin M, Kahn MF. Primary Sjögren's syndrome (SS) and malignant lymphoma. Scand J Rheumat 1995;24:342 5 .

25 Shin S, Sheibani K, Fishleder A, Ben-Ezra J, Bailey A, Koo $\mathrm{CH}$, et al. Monocytoid B-cell lymphoma in patients with Sjögren's syndrome. A clinicopathologic study of 13 patients. Hum Pathol 1991;22:422-30

26 Wilke WS, Tubbs RR, Bukowski RM, Currie TE, Calabrese LH, Weiss RA, et al. T cell lymphoma occurring in Sjögren's syndrome. Arthritis Rheum 1984;27:951-5.

27 Isenberg DA, Griffiths MH, Rustin M, Webb MWS, Souhami RL. T cell lymphoma in a patient with longstanding rheumatoid arthritis and Sjögren's syndrome. Arthritis Rheum 1987;30:115-17.

28 Schuurman HJ, Gooszen HC, Tan IWN, Kluin PM Wagenaar SS, van Unnik JAM. Low-grade lymphoma of immature T-cell phenotype in a case of lymphocytic interstitial pneumonia and Sjögren's syndome. Histopathology 1987:11:1193-204.

29 Rustin MHA, Isenberg DA, Griffiths MH, Gilkes JJH. Sjögren's syndrome and pleomorphic T-cell lymphoma presenting with skin involvement. J Soc Med 1988;81: $47-9$.

30 Van der Valk PGM, Hollema H, van Voorst Vander PC, Brinker M, Poppema S. Sjögren's syndrome with specific cutaneous manifestations and multifocal clonal T-cell populations progressing to a cutaneous pleomorphic T-cell lymphoma. Am J Clin Pathol 1989;92:357-61.

31 Martin-Santos J, Carretero L, Armentia A, Alonso E, Gil I. Hodgkin's disease occurring in primary Sjögren's syndrome. Ann Rheum Dis 1990;49:646-7.

32 Vivancos J, Bosch X, Grau J, Coca A, Font J. Development of Hodgkin's disease in the course of primary Sjögren's syndrome. Br J Rheumatol 1992;31:561-3.

33 Ponge T, Champetier de Ribes F, Ponge A, Garand R, Cotin S. Chronic myelomonocytic leukemia and primary Sjögren's syndrome. Clin Rheumatol 1988;7:110-13.

34 Ota T, Wake A, Eto S, Kobayashi T. Sjögren's syndrome terminating in multiple myeloma. Scand J Rheumatol $1995 ; 24: 316-18$

35 Talal N, Sokoloff L, Barth WF. Extra salivary lymphoid abnormalities in Sjögren's syndrome (reticulum cell abnormalities in Sjogren's syndrome (reticulum cell Am J Med 1967;43:50-65.

36 Sutcliffe N, Inanc M, Speight P, Isenberg D. Predictors of ymphoma development in primary Sjögren's syndrome. Semin Arthritis Rheum 1998;28:80-7.

37 Voulgarelis M, Dafni UG, Isenberg DA, Moutsopoulos HM. Malignant lymphoma in primary Sjögren's syndrome: a multicenter, retrospective, clinical study by the European Concerted Action on Sjögren's syndrome. Arthritis Rheum 1999;42:1765-72.

38 Tzioufas A, Boumba D, Skopouli F, Moutsopoulos H. Mixed monoclonal cryoglobulinemia and monoclonal rheumatoid factor cross-reactive idiotypes as predictive factors for the development of lymphoma in primary Sjögren's syndrome. Arthritis Rheum 1996;39:767-72.

39 Jordan R, Speight P. Lymphoma in Sjögren's syndrome. From histopathology to molecular pathology. Oral Surg Michalsky JP, Daniels TE, Talal N, Grey HM. Beta-2Michalsky JP, Daniels TE, Talal N, Grey HM. Beta-2-
microglobulin and lymphocytic infiltration in Sjögren's syndrome. N Engl J Med 1975;293:1228-31.

41 Pertovaara M, Korpela M, Kouri T, Pasternack A. The occurrence of renal involvement in primary Sjogren's syndrome: a study of 78 patients. Rheumatology 1999;38: $1113-20$.

42 Martens PB, Pillemer SR, Jacobsson LT, O'Fallon WM, Matteson EI. Survivorship in a population based cohort of patients with Siögren's syndrome. J Rheumatol 1999.26: 1296-300. 